\title{
ARTICLE Quality and Lactic Acid Bacteria Diversity of Pork Salami Containing Kimchi Powder
}

\section{IOPEN ACCESS}

\section{Received June 21, 2018 \\ Revised July 30, 2018 \\ Accepted July 30, 2018}

*Corresponding author : Aera Jang Department of Applied Animal Science, Kangwon National University, Chuncheon 24341, Korea

Tel: +82-33-250-8643

Fax: +82-33-251-7719

E-mail: ajang@kangwon.ac.kr

\author{
Ji Yeol Yoon ${ }^{1,2}$, Dongwook Kim ${ }^{1}$, Eun-Bae Kim¹, Sung-Ki Lee ${ }^{1}$, Mooha Lee ${ }^{3}$, \\ and Aera Jang ${ }^{1, *}$ \\ ${ }^{1}$ Department of Applied Animal Science, College of Animal Life Science, Kangwon \\ National University, Chuncheon 24341, Korea \\ ${ }^{2}$ R\&D Center, Paldo Co. Ltd., Yongin 17086, Korea \\ ${ }^{3}$ Korean Academy of Science \& Technology, Seongnam 13630, Korea
}

\begin{abstract}
We investigated the quality properties and bacteria diversity of pork salami containing homemade kimchi powder (KP). Pork salamis were manufactured with commercial starter culture (control), and 1\% KP (KP1), 3\% KP (KP3), and 5\% KP (KP5). The salami was fermented and aged for 2 days and 56 days, respectively. The $\mathrm{pH}$ and Aw values of salamis with KP were significantly lower than that of the control $(\mathrm{p}<0.05)$. The 2-thiobarbituric acid reactive substance values of all salamis with KP increased but were below $0.2 \mathrm{mg} \mathrm{MDA} / \mathrm{kg}$. Salamis with KP, decreased the $\mathrm{L}^{*}$ value, but increased the $\mathrm{a}^{*}$ and $\mathrm{b}^{*}$ values $(\mathrm{p}<0.05)$. The Lactobacillus count was significantly higher in the salamis with KP than in the control by day $14(\mathrm{p}<0.05)$. The number of Leuconostoc was higher in salamis with KP than in the control and was the highest in salamis in KP1. The KP1 protected lipid oxidation and showed low TBARS value of pork salami compared to the control. This study demonstrates that KP can improve pork salami properties and can serve as a potential natural compounds for fermented meat prodcuts like Metzgerei.
\end{abstract}

Keywords kimchi, pork salami, lactic acid bacteria, microbial community, quality characteristics

\section{Introduction}

Fermented meat products are known to contain bioactive substances. Fermented sausages, a traditional food of Europe, are made from the fermentation of lactic acid bacteria ( $\mathrm{LAB})$ and are produced under controlled temperature and relative humidity conditions (Coloretti et al., 2014). Fermented sausages are generally produced without any heat treatment throughout the process of fermentation, aging, and drying (Paik and Lee, 2014). The manufacturing process of fermented sausages has two main steps: fermentation and aging, of which fermentation is the most important. During fermentation and aging, microbial changes to the LAB composition, and chemical changes such as the production of flavor compounds, result from the degradation of

(C) Korean Society for Food Science of Animal Resources. This is an open access article distributed under the terms of the Creative Commons Attribution Non-Commercial License (http://creativecommons.org/licences/by-nc/3.0) which permits unrestricted non-commercial use, distribution, and reproduction in any medium, provided the original work is properly cited. 
proteins and lipids (Ko and Yang, 1999). The typical characteristics of fermented sausages are a product of the biochemical and physical changes that resulted during fermentation and aging. In addition, these meats cannot be pasteurized, and are therefore highly vulnerable to the growth of undesirable microorganisms. Therefore, the selection of favorable conditions that encourage the growth of desirable and safe microflora, and restrict the growth of spoiling bacteria, is essential for the shelflife extension of fermented sausages (Aro et al., 2010; Park and Lee, 2012).

Kimchi, a traditional fermented food of Korea, is a very popular side dish and manufactured from the addition of various components, including ginger, red pepper, green onion, garlic, fermented shrimp, or fish. The antimicrobial activity of kimchi has been reported by many scientists (Park et al., 2011) that various LAB, including Pediococcus spp., Leuconostoc spp., Lactobacillus spp., and Weissella spp., participate in the fermentation, and Pediococcus pentosaceus, a LAB derived from kimchi, produces a bacteriocin called pediocin, which has antimicrobial activity (Jang et al., 2014). LAB are used to preserve fermented food products such as dairy foods, vegetables, and meats, and are vital in meat fermentation (Lee et al., 2006). The major role of LAB is to produce lactate rapidly and reliably from the sugars, usually glucose and sucrose, that are added to the sausage mix (Ahmad and Srivastava, 2007). Growth of LAB can inhibit the growth of pathogenic and spoilage bacteria in a number of ways, including the production of a wide range of inhibitory substances like lactic acid, diacetyl, and bacteriocins, and competition for attachment or adhesion (Hugas, 1998). El-Adawy (2001) showed that the addition of Pediococcus pentosaceus to food products is crucial, not only for its fermentative role, but also for its suppressive effect on the growth of undesirable and pathogenic microorganisms. Leuconostoc mesenteroides is primarily involved in initial fermentation and produced lactic acid and carbon dioxide (Lee et al., 1990; Park and Cheigh, 2000). Mcdonald et al. (1990) reported that Leuconostoc mesenteroides grows during early fermentation and that Lactobacillus plantarum terminates the fermentation. Pediococcus pentosaceus and Leuconostoc mesenteroides converts sucrose into dextran by dextransucrase and is used in the fermentation of sausages because it prevents the growth of pathogenic bacteria (Jo et al., 2008; Shukla and Goyal, 2013).

The microbial composition of kimchi has been identified using conventional methods, but these studies used limited types of media and culture conditions and would have missed bacteria that are unculturable under general laboratory conditions (Kim and Chun, 2005). A few studies have allowed for the characterization of the microbial community in kimchi using traditional culture-dependent and independent methods, such as polymerase chain reaction (PCR), ribosomal DNA restriction analysis (ARDRA), and denaturing gradient gel electrophoresis (DGGE) (Park and Lee, 2012). The 16S rRNA gene of microorganisms have specific sequence and differ between species and allows identification of bacteria to the genus level (Han et al., 1998).

The objectives of the present study were to evaluate the effect of kimchi powder levels as a starter on the quality characteristics and microbial diversity of pork salami during fermentation and aging.

\section{Materials and Methods}

\section{Preparation of kimchi powder (KP)}

Chinese cabbage kimchi was manufactured with following procedure and the ingredients according to one of traditional methods for kimchi in Jelanamdo. Chinese cabbages were dipped in brine for $8 \mathrm{~h}$, then washed with tap water and drained. The brined Chinese cabbages were mixed with the following seasoning and spices: white radish (10.0\%), chives $(1.0 \%)$, mustard leaves $(1.0 \%)$, glutinous rice gruel $(6.0 \%)$, red pepper powder $(3.0 \%)$, sand lance sauce $(0.5 \%)$, salted shrimp 
$(0.5 \%)$, fresh shrimp $(0.5 \%)$, plum extracts $(1.0 \%)$, garlic $(1.0 \%)$, ginger $(0.5 \%)$, salt $(0.5 \%)$, and $9.0 \%$ broth. The broth was extract from $2.5 \%$ dried pollack head, $0.5 \%$ large-eyed herring, $5.0 \%$ onion, $0.2 \% \mathrm{kelp}, 1.0 \%$ spring onion in $1 \mathrm{~L}$ of water. The kimchi and seasoning mixture was ripened for 14 days at room temperature $\left(23 \pm 1^{\circ} \mathrm{C}\right)$. The kimchi mixture was lyophilized in a vacuum using a freeze-dryer (FDU-1200, Eyela, Japan) and used as KP and stored at $-20^{\circ} \mathrm{C}$ until further use.

\section{Pork salami preparation}

Pork salmi was prepared by the method of Di Cagno et al. (2008) with slight modification. Fresh ham $(66 \mathrm{~kg})$ and pork back fat $(15 \mathrm{~kg})$ were purchased from a local market and kept below $4^{\circ} \mathrm{C}$ during preparation. Fresh ham and pork back fat were ground using a meat chopper (M-22, Daewoo Kitchen Co., Korea) with a disc of $6 \mathrm{~mm}$ diameter. Pork salamis were manufactured with the following formulation; $85.00 \%$ fresh ham, $15.00 \%$ pork back fat, $2.00 \%$ salt, $0.26 \%$ prague powder, $1.00 \%$ sucrose, $0.05 \%$ sodium erythorbate, $0.75 \%$ dextrose, $0.35 \%$ whole mustard seed, $0.70 \%$ black pepper, $0.30 \%$ garlic powder, $0.06 \%$ ground ginger, $0.06 \%$ nutmeg, $1.00 \%$ carrageenan, and $0.10 \%$ smoke solution. Freeze-dried KP was mixed with pork salami batter at the levels of $1 \%(\mathrm{KP} 1), 3 \%$ (KP3) and 5\% (KP5). Salt was added to sausages to adjust according to the salt content of KP (12.17\%), resulting in a salt content for each treatment of $2.00 \%$ for the control, $1.88 \%$ for KP1, $1.65 \%$ for KP3, and $1.42 \%$ for KP5. The control sausage was manufactured using a commercial starter culture (Lyocarni SBM-52, Clerici Sacco Co., Cadorago, Italy), which consists of Staphylococcus carnosus, Staphylococcus xylosus, Pediococcus pentosaceus, and Pediococcus acidilactici. After mixing with the starter culture, the salami meat batters were stuffed into collagen casings. Then it was transferred to a chamber controlling temperature and humidity under the conditions shown in Table 1.

\section{Proximate composition, $\mathrm{pH}$ and water activity $\left(\mathrm{A}_{\mathrm{w}}\right)$ of pork salami}

The proximate composition of salamis was measured according to the methods of AOAC (1995). The moisture content of salamis was measured by weight loss after $12 \mathrm{~h}$ of drying at $105^{\circ} \mathrm{C}$ (method 940.26 ). The protein content was measured using the Kjeldahl method (method 920.152). The salt content was measured by titration using the Mohr method (Kirk and Sawyer, 1991). The $\mathrm{pH}$ values of pork salamis were measured by first blending $10 \mathrm{~g}$ of pork salami with $90 \mathrm{~mL}$ distilled water for $30 \mathrm{~s}$ with a homogenizer (PolyTron ${ }^{\circledR}$ PT-2500E, Kinematica, Switzerland), and probing with a pH meter (Orion 230A, USA). AW of pork salamis was measured using an aquaspector (AQS-2-TC, NAGY, Germany).

\section{Color and texture profile analysis (TPA)}

Color measurements were conducted with a color meter (CR-300, Minolta Co., Japan). The instrument was calibrated with white tiles. $\mathrm{L}^{*}$ value (lightness), $\mathrm{a}^{*}$ value (redness), and $\mathrm{b}^{*}$ value (yellowness) were determind on the surface of samples

Table 1. Conditions in the humidity chamber during fermentation and ageing of the pork salami added with kimchi powder

\begin{tabular}{lccc}
\hline \multirow{2}{*}{ Time $(\mathrm{d})$} & Process & \multicolumn{2}{c}{ Condition } \\
\cline { 3 - 4 } 0 & Conditioning & Temperature $\left({ }^{\circ} \mathrm{C}\right)$ & Humidity $(\% \mathrm{RH})$ \\
1 & Fermentation & 25 & 65 \\
2 & Fermentation & 23 & 95 \\
3 & Ageing & 23 & 92 \\
$5-56$ & Ageing & 20 & 90 \\
\hline
\end{tabular}


$(\mathrm{n}=10)$. The colorimeter was calibrated using white standard plate $(\mathrm{Y}=93.60, \mathrm{x}=0.3134$, and $\mathrm{y}=0.3194)$.

Texture profile was measured at room temperature $\left(23^{\circ} \mathrm{C}\right)$ with a texture analyzer (TA-1, LLOYD Instruments, USA). The test conditions were as follows: with $50 \mathrm{~mm}$ diameter probe, compression speed $10 \mathrm{~mm} / \mathrm{min}$, wait time $5 \mathrm{~s}$, trigger $0.01 \mathrm{kgf}$, sample compressed $70 \%$. Pork salamis were cut into sections of $1.0 \mathrm{~cm}$ in height and $1.0 \mathrm{~cm}$ in width. Data for the hardness (kgf), adhesiveness (Nmm), gumminess (kgf), chewiness (kgf), and cohesiveness were collected and analyzed.

\section{Thiobarbituric acid reaction substances (TBARS)}

The lipid oxidation in pork salamis was determined according to the water vapor distillation method of Witte et al. (1970). A sample of $10 \mathrm{~g}$ was placed in a conical tube, to which a $25 \mathrm{~mL}$ solution of $20 \%$ trichloroacetic acid (TCA) was added and homogenized for $30 \mathrm{~s}$ at $14,000 \mathrm{rpm}$ using a homogenizer (Polytron ${ }^{\circledR}$ PT-2500E, Kinematica, Switzerland). The resulting slurry was transferred to a mass cylinder and diluted to $50 \mathrm{~mL}$ with distilled water. The sample was filtered through Whatman No. 1 filter paper. Then, $5 \mathrm{~mL}$ of the filtrate was transferred to a test tube, and $5 \mathrm{~mL}$ of fresh chilled $0.005 \mathrm{mM} \mathrm{2-}$ thiobarbituric acid solution was added. All samples in test tubes were kept in the dark for $15 \mathrm{~h}$ at room temperature. The absorbance of color was determined in a UV/VIS spectrophotometer (M2e, Molecular Devices, USA) at $530 \mathrm{~nm}$ and calculated by following equation.

TBARS value $(\mathrm{mg}$ malondialdehyde $/ \mathrm{kg}$ sample $)=($ sample absorbance - blank absorbance $) \times 5.2$

\section{Lactic acid bacteria (LAB) and microbial analysis}

For LAB, $10 \mathrm{~g}$ of salami sample was homogenized in $90 \mathrm{~mL} 0.1 \%$ peptone water for $4 \mathrm{~min}$ in a stomacher (Bag Mixer 400, Interscience, France). A 10-fold serial dilution was made, of which $100 \mu \mathrm{L}$ samples of appropriate dilutions were spread on Lactobacilli MRS agar (Difco Laboratories, USA) and incubated at $35^{\circ} \mathrm{C}$ for $48 \mathrm{~h}$. In addition, total microorganisms and $E$. coli/coliforms were counted using petrifilm (Aerobic count plate, Coliform count plate, 3M, USA) after incubation at $37^{\circ} \mathrm{C}$ for $48 \mathrm{~h}$. DNA was extracted from pork salami containing kimchi and kimchi-powder itself using a DNA kit (MachereyNagel GmbH and Co. KG, Germany). The 16S rRNA genes of extracted DNA were amplified on a Trio-Thermoblock thermocycler (Biometra, Germany). Each PCR was set in a volume of $23.5 \mu \mathrm{L}$ with $17.85 \mu \mathrm{L}$ sterile distilled water, $2.5 \mu \mathrm{L}$ $10 \times$ PCR buffer, $0.5 \mu \mathrm{L} \mathrm{MgCl}_{2}, 2.0 \mu \mathrm{L}$ dNTP mix, $0.15 \mu \mathrm{L}$ Ex-Taq polymerase (Takara, Japan), $0.5 \mu \mathrm{L}$ each of forward and reverse primers (10 pmoles), and $1.0 \mu \mathrm{L}$ purified DNA $(5 \mathrm{ng} / \mu \mathrm{L})$. Thermocycling conditions were as follows: 3 min at $94^{\circ} \mathrm{C}$ for initial denaturation; followed by 30 cycles of $45 \mathrm{~s}$ at $94^{\circ} \mathrm{C}, 1 \mathrm{~min}$ at $55^{\circ} \mathrm{C}$ and $1.5 \mathrm{~min}$ at $72^{\circ} \mathrm{C}$; and final extension for 10 min at $72^{\circ} \mathrm{C}$, after which the PCR mixture was cooled to $4{ }^{\circ} \mathrm{C}$. Amplification products were analyzed by electrophoresis at 135 $\mathrm{V}$ for $30 \mathrm{~min}$ on a $2 \%$ agarose gel in $0.5 \times$ TAE buffer. PCR products were sequenced using the Miseq sequencer system (Illumina, USA).

\section{Sensory evaluations}

Thirteen panelists from the Department of Animal Product and Food Science at Kangwon National University in Korea provided sensory evaluations of the sausages $(n=13)$. Pork salamis were cut and served to the panelists in random order. The sensory properties of the pork salami were evaluated for color, appearance, specific odor, flavor, acidity, preference, texture, and overall acceptability using a 9-point descriptive scale: color (1=extremely undesirable, $9=$ extremely desirable), appearance (1=extremely undesirable, $9=$ extremely desirable), specific odor (1=extremely undesirable, $9=$ extremely desirable), flavor 
(1=extremely undesirable, 9=extremely desirable), acidity ( $1=$ weak acidity, 9=strong acidity), preference $(1=$ extremely undesirable, $9=$ extremely desirable), texture ( $1=$ extremely tough, $9=$ extremely tender $)$, and overall acceptability $(1=$ extremely undesirable, $9=$ extremely desirable).

\section{Statistical analysis}

All data collected were subjected to one-way analysis of variance (ANOVA) according to the general linear model procedures for SAS software (ver. 9.2. SAS Institute Inc., USA). Mean values and standard error of the mean value of sample were reported. When analysis of variance indicated a significant treatment effect, Tukey's test was used to compare the mean values, and a p-value $<0.05$ was considered statistically significant.

\section{Results and Discussion}

\section{Physicochemical properties of pork salami containing kimchi powder (KP)}

The proximate compositions of pork salami containing KP are presented in Table 2. Until day 35 of aging period, the moisture content of the pork salamis decreased while the crude protein and crude fat contents of the salamis increased

Table 2. Proximate compositions of pork salamis added with different level of kimchi powder

\begin{tabular}{|c|c|c|c|c|c|c|c|c|c|c|c|}
\hline \multirow{2}{*}{ Items } & \multirow{2}{*}{ Treatments ${ }^{1)}$} & \multicolumn{10}{|c|}{ Days } \\
\hline & & 0 & 7 & 14 & 21 & 28 & 35 & 42 & 49 & 56 & SEM \\
\hline \multirow[t]{5}{*}{ Moisture } & $\mathrm{CON}$ & $62.26^{\mathrm{Aa}}$ & $52.15^{\mathrm{Bb}}$ & $44.13^{\mathrm{Ac}}$ & $39.27^{\mathrm{Ad}}$ & $33.39^{\mathrm{Be}}$ & $30.99^{\mathrm{Cfg}}$ & $31.22^{\mathrm{Af}}$ & $30.97^{\mathrm{Cfg}}$ & $30.61^{\mathrm{Cg}}$ & 0.164 \\
\hline & KP1 & $62.10^{\mathrm{Aa}}$ & $53.68^{\mathrm{Ab}}$ & $42.93^{\mathrm{Bc}}$ & $37.60^{\mathrm{Bd}}$ & $33.32^{\mathrm{Be}}$ & $31.92^{\mathrm{ABf}}$ & $31.55^{\mathrm{Afg}}$ & $31.03^{\mathrm{Cg}}$ & $31.12^{\mathrm{BCg}}$ & 0.223 \\
\hline & KP3 & $62.26^{\mathrm{Aa}}$ & $53.42^{\mathrm{Ab}}$ & $43.69^{\mathrm{ABc}}$ & $37.68^{\mathrm{Bd}}$ & $33.90^{\mathrm{Be}}$ & $32.04^{\mathrm{Af}}$ & $32.09^{\mathrm{Af}}$ & $32.35^{\mathrm{Af}}$ & $31.74^{\mathrm{ABf}}$ & 0.191 \\
\hline & KP5 & $60.43^{\mathrm{Ba}}$ & $52.74^{\mathrm{Bb}}$ & $44.18^{\mathrm{Ac}}$ & $37.68^{\mathrm{Bd}}$ & $34.95^{\mathrm{Ae}}$ & $31.44^{\mathrm{BCf}}$ & $31.96^{\mathrm{Af}}$ & $31.69^{\mathrm{Bf}}$ & $32.05^{\mathrm{Af}}$ & 0.274 \\
\hline & SEM & 0.171 & 0.187 & 0.280 & 0.178 & 0.265 & 0.176 & 0.263 & 0.152 & 0.236 & \\
\hline \multirow{5}{*}{$\begin{array}{l}\text { Crude } \\
\text { protein }\end{array}$} & $\mathrm{CON}$ & $22.52^{\mathrm{Ag}}$ & $27.38^{\mathrm{Af}}$ & $33.89^{\mathrm{Ae}}$ & $36.15^{\mathrm{Bd}}$ & $40.29^{\mathrm{Ac}}$ & $41.72^{\mathrm{Abc}}$ & $42.49^{b}$ & $42.03^{\mathrm{Bbc}}$ & $47.23^{\mathrm{ABa}}$ & 0.621 \\
\hline & KP1 & $22.48^{\mathrm{Af}}$ & $26.41^{\mathrm{Ae}}$ & $35.22^{\mathrm{Ad}}$ & $38.59^{\mathrm{ABc}}$ & $40.43^{\mathrm{Abc}}$ & $41.14^{\mathrm{Ab}}$ & $41.37^{\mathrm{Ab}}$ & $41.96^{\mathrm{Bb}}$ & $48.21^{\mathrm{Aa}}$ & 0.792 \\
\hline & KP3 & $22.46^{\mathrm{Ae}}$ & $28.65^{\text {Ad }}$ & $35.25^{\mathrm{Ac}}$ & $38.28^{\mathrm{ABc}}$ & $41.42^{\mathrm{Ab}}$ & $42.67^{\mathrm{Ab}}$ & $44.39^{\mathrm{Aab}}$ & $41.91^{\mathrm{Bb}}$ & $46.57^{\mathrm{ABa}}$ & 1.055 \\
\hline & KP5 & $23.87^{\mathrm{Ae}}$ & $27.97^{\mathrm{Ad}}$ & $34.18^{\mathrm{Ac}}$ & $39.24^{\mathrm{Ab}}$ & $40.83^{\mathrm{Ab}}$ & $44.13^{\mathrm{Aa}}$ & $44.88^{\mathrm{Aa}}$ & $45.64^{\mathrm{Aa}}$ & $44.93^{\mathrm{Ba}}$ & 1.018 \\
\hline & SEM & 0.811 & 0.819 & 0.858 & 0.816 & 0.453 & 1.118 & 1.088 & 1.034 & 0.824 & \\
\hline \multirow[t]{5}{*}{ Crude fat } & $\mathrm{CON}$ & $12.86^{\mathrm{Ad}}$ & $18.05^{\mathrm{Ac}}$ & $19.66^{\mathrm{Ac}}$ & $21.92^{\mathrm{Ab}}$ & $23.67^{\mathrm{Aab}}$ & $24.02^{\mathrm{Aa}}$ & $24.02^{\mathrm{Aa}}$ & $24.54^{\mathrm{Aa}}$ & $19.67^{\mathrm{Ac}}$ & 0.611 \\
\hline & KP1 & $12.83^{\mathrm{Ae}}$ & $16.99^{\mathrm{ABd}}$ & $18.88^{\mathrm{Ac}}$ & $20.94^{\mathrm{Ab}}$ & $22.94^{\mathrm{ABa}}$ & $23.16^{\mathrm{Aa}}$ & $22.86^{\mathrm{ABa}}$ & $22.22^{\mathrm{ABab}}$ & $18.41^{\text {Acd }}$ & 0.571 \\
\hline & KP3 & $12.83^{\mathrm{Ad}}$ & $15.37^{\mathrm{Bd}}$ & $18.21^{\mathrm{Ac}}$ & $21.17^{\text {Aab }}$ & $21.83^{\mathrm{Bab}}$ & $21.48^{\mathrm{Aab}}$ & $19.83^{\mathrm{Babc}}$ & $22.48^{\mathrm{Aa}}$ & $19.38^{\mathrm{Abc}}$ & 0.895 \\
\hline & KP5 & $13.37^{\mathrm{Ac}}$ & $16.52^{\mathrm{ABb}}$ & $18.88^{\mathrm{Aab}}$ & $20.53^{\mathrm{Aa}}$ & $21.63^{\mathrm{Ba}}$ & $21.13^{\mathrm{Aa}}$ & $19.88^{\mathrm{Ba}}$ & $19.26^{\mathrm{Ba}}$ & $20.38^{\mathrm{Aa}}$ & 0.845 \\
\hline & SEM & 0.616 & 0.724 & 0.706 & 0.481 & 0.431 & 0.933 & 0.912 & 0.919 & 0.783 & \\
\hline \multirow{5}{*}{$\begin{array}{l}\text { Crude } \\
\text { ash }\end{array}$} & $\mathrm{CON}$ & $2.35^{\mathrm{Aa}}$ & $2.42^{\mathrm{Aa}}$ & $2.33^{\mathrm{Aa}}$ & $2.65^{\mathrm{Aa}}$ & $2.65^{\mathrm{Aa}}$ & $3.27^{\mathrm{Aa}}$ & $2.27^{\mathrm{Aa}}$ & $2.46^{\mathrm{Ba}}$ & $2.65^{\mathrm{Aa}}$ & 0.379 \\
\hline & KP1 & $2.59^{\mathrm{Ab}}$ & $2.93^{\mathrm{Ab}}$ & $2.97^{\mathrm{Ab}}$ & $2.87^{\mathrm{Ab}}$ & $3.30^{\mathrm{Aab}}$ & $3.78^{\mathrm{Aab}}$ & $4.22^{\mathrm{Aab}}$ & $4.79^{\mathrm{Aa}}$ & $4.62^{\mathrm{Aab}}$ & \\
\hline & KP3 & $2.46^{\mathrm{Aa}}$ & $2.33^{\mathrm{Aa}}$ & $2.85^{\mathrm{Aa}}$ & $2.87^{\mathrm{Aa}}$ & $2.85^{\mathrm{Aa}}$ & $3.81^{\mathrm{Aa}}$ & $3.69^{\mathrm{Aa}}$ & $3.73^{\mathrm{ABa}}$ & $2.44^{\mathrm{Aa}}$ & 0.596 \\
\hline & KP5 & $2.34^{\mathrm{Ab}}$ & $2.77^{\mathrm{Aab}}$ & $2.76^{\mathrm{Aab}}$ & $2.54^{\mathrm{Aab}}$ & $2.60^{\mathrm{Aab}}$ & $3.30^{\mathrm{Aab}}$ & $3.28^{\mathrm{Aab}}$ & $3.41^{\mathrm{ABa}}$ & $2.64^{\mathrm{Aab}}$ & 0.304 \\
\hline & SEM & 0.391 & 0.341 & 0.334 & 0.492 & 0.241 & 0.791 & 0.591 & 0.502 & & \\
\hline
\end{tabular}

${ }^{\mathrm{A}-\mathrm{C}}$ Means within same column with different superscript letters differ significantly at $\mathrm{p}<0.05$.

${ }^{\mathrm{a}-\mathrm{g}}$ Means within same row with different superscript letters differ significantly at $\mathrm{p}<0.05$.

${ }^{1)}$ Con, pork salami added with commercial starter; KP1, pork salami added with $1 \%$ kimchi powder; KP3, pork salami added with $3 \%$ kimchi powder; KP5, pork salami added with $5 \%$ kimchi powder. 
significantly $(\mathrm{p}<0.05)$. There was no significant difference in crude ash composition between sausages. The moisture content rapidly decreased between the initial phase $(60.43 \%$ to $62.26 \%)$ and aging day $21(37.60 \%$ to $39.27 \%)$ in all pork salamis and were significantly lower at day 56 (30.61-32.05). The crude protein contents of all pork salamis were increased by the end of storage and showed $22.46 \%-23.87 \%$ at initial phase and $44.93 \%-48.21 \%$ at the end of aging ( $<<0.05$ ). In addition, Lee et al. (2008) demonstrated that breakfast sausages with hot air-dried KP had significantly higher water content than without KP. The crude fat content of pork salamis in KP1 increased from $12.83 \%$ to $22.94 \%$ until day 28 .

The changes in $\mathrm{pH}$ values and Aw of pork salamis with KP were shown in Table 3. The $\mathrm{pH}$ values of all pork salamis in $\mathrm{KP} 1$ were decreased significantly from day 1 to at the end of the aging period. The $\mathrm{pH}$ values of all pork salamis varied from 5.62-5.71 to 4.41-4.60 during aging period. Muguerza et al. (2002) observed a similar change in $\mathrm{pH}$ of fermented sausages with $10 \%, 20 \%$ and $30 \%$ pork back fat, and reported that the initial $\mathrm{pH}$ values of fermented sausages ranged from 6.03 to 6.29 and the final $\mathrm{pH}$ values on the 28th day ranged from 4.70 to 4.92. According to Campagnol et al. (2011), the reduction in $\mathrm{pH}$ values in fermenting sausage prior to the 14th day of production is caused by the accumulation of lactic acid from LAB metabolizing carbohydrates such as sucrose and glucose. The $\mathrm{pH}$ of fermented sausages rapidly declined to $4.8-4.9$ by day 4 , decreased somewhat more ( $\mathrm{pH}$ 4.5-4.6) by the end of the fermentation (day 7), and maintained at this $\mathrm{pH}$ level during ripening periods (Chouliara et al., 2006). These results are similar to the present results. Another study found that $\mathrm{pH}$ values of fermented sausages with added kimchi were 5.53-5.54 at day 0, and were 4.30-4.33 at day 3 (Kang et al., 2012). Park and Lee (2012) reported that $\mathrm{LAB}$ reduce $\mathrm{pH}$ values through the utilization of carbohydrates and production of organic acids, and $\mathrm{LAB}$ counts reach their maximum values between day 1 and day 2 . The $\mathrm{pH}$ values of the pork salami with KP were lower than that of the control and ranged from 4.41 to 4.51 at end of aging period. These results reveal that the higher the concentration of KP, the lower the $\mathrm{pH}$ value of pork salami. It was apparent that acidification in the KPs was stronger than that in the control sausage. The reduction in the $\mathrm{pH}$ value below 5.0 was due to LAB and helps to reduce the aging time by the promotion of dryness and to increase shelf life by the inhibition of spoilage microorganisms.

The $A_{W}$ of the pork salamis decreased until day 42 (Table 3). The $A_{W}$ values declined to approximately 0.82 in the control

Table 3. The changes in $\mathrm{pH}$ and $\mathrm{A}_{\mathrm{W}}$ value of pork salami added with different level of kimchi powder

\begin{tabular}{|c|c|c|c|c|c|c|c|c|c|c|c|c|c|c|c|}
\hline \multirow{2}{*}{ Items } & \multirow{2}{*}{$\begin{array}{l}\text { Treat- } \\
\text { ments }^{1)}\end{array}$} & \multicolumn{14}{|c|}{ Days } \\
\hline & & 0 & 1 & 2 & 3 & 5 & 7 & 14 & 21 & 28 & 35 & 42 & 49 & 56 & SEM \\
\hline \multirow[t]{5}{*}{$\mathrm{pH}$} & $\mathrm{CON}$ & $5.71^{\mathrm{ABa}}$ & $5.72^{\mathrm{Da}}$ & $5.03^{\mathrm{Cb}}$ & $4.85^{\mathrm{Ac}}$ & $4.84^{\mathrm{Ad}}$ & $4.75^{\mathrm{Ae}}$ & $4.69^{\mathrm{Af}}$ & $4.66^{\mathrm{Ag}}$ & $4.64^{\mathrm{Ag}}$ & $4.65^{\mathrm{Ag}}$ & $4.65^{\mathrm{Ag}}$ & $4.51^{\mathrm{Ai}}$ & $4.60^{\mathrm{Ah}}$ & 0.006 \\
\hline & KP1 & $5.74^{\mathrm{Ab}}$ & $5.88^{\mathrm{Aa}}$ & $5.15^{\mathrm{Ac}}$ & $4.75^{\mathrm{Bd}}$ & $4.65^{\mathrm{Be}}$ & $4.60^{\mathrm{Bf}}$ & $4.61^{\mathrm{Bf}}$ & $4.54^{\mathrm{Bg}}$ & $4.51^{\mathrm{Bh}}$ & $4.50^{\mathrm{Bh}}$ & $4.52^{\text {Bgh }}$ & $4.38^{\mathrm{Bi}}$ & $4.51^{\mathrm{Bh}}$ & 0.007 \\
\hline & KP3 & $5.68^{\mathrm{Bb}}$ & $5.86^{\mathrm{Ba}}$ & $5.07^{\mathrm{Bc}}$ & $4.70^{\mathrm{Dd}}$ & $4.64^{\mathrm{Ce}}$ & $4.53^{\mathrm{Cf}}$ & $4.53^{\mathrm{Cfg}}$ & $4.51^{\mathrm{Cg}}$ & $4.51^{\mathrm{Bg}}$ & $4.44^{\mathrm{Ci}}$ & $4.47^{\mathrm{Dh}}$ & $4.35^{\mathrm{Dk}}$ & $4.42^{\mathrm{Cj}}$ & 0.007 \\
\hline & KP5 & $5.62^{\mathrm{Cb}}$ & $5.76^{\mathrm{Ca}}$ & $5.14^{\mathrm{Ac}}$ & $4.73^{\mathrm{Cd}}$ & $4.62^{\mathrm{De}}$ & $4.53^{\mathrm{Cf}}$ & $4.52^{\mathrm{Cfg}}$ & $4.50^{\mathrm{Cgh}}$ & $4.48^{\mathrm{Bi}}$ & $4.49^{\mathrm{Bhi}}$ & $4.50^{\mathrm{Cghi}}$ & $4.36^{\mathrm{Ck}}$ & $4.41^{\mathrm{Cj}}$ & 0.007 \\
\hline & SEM & 0.013 & 0.005 & 0.010 & 0.003 & 0.005 & 0.004 & 0.003 & 0.009 & 0.010 & 0.003 & 0.004 & 0.004 & 0.006 & \\
\hline \multirow[t]{5}{*}{ Aw } & $\mathrm{CON}$ & $0.928^{\mathrm{Bd}}$ & $0.940^{\mathrm{ABbc}}$ & $0.946^{\mathrm{ABa}}$ & $0.941^{\mathrm{ABb}}$ & $0.936^{\mathrm{Bc}}$ & $0.932^{\mathrm{Ad}}$ & $0.931^{\mathrm{Ad}}$ & $0.881^{\mathrm{ABe}}$ & $0.848^{\mathrm{Bf}}$ & $0.837^{\mathrm{Bg}}$ & $0.829^{\mathrm{Ah}}$ & $0.846^{\mathrm{Bf}}$ & $0.820^{\mathrm{Bi}}$ & 0.001 \\
\hline & KP1 & $0.938^{\mathrm{Ab}}$ & $0.945^{\mathrm{Aa}}$ & $0.947^{\mathrm{Aa}}$ & $0.945^{\mathrm{Aa}}$ & $0.944^{\mathrm{Aa}}$ & $0.933^{\mathrm{Ac}}$ & $0.918^{\mathrm{Bd}}$ & $0.883^{\mathrm{Ae}}$ & $0.855^{\mathrm{ABf}}$ & $0.841^{\mathrm{ABg}}$ & $0.826^{\mathrm{ABh}}$ & $0.837^{\mathrm{Cg}}$ & $0.830^{\mathrm{Ah}}$ & 0.002 \\
\hline & KP3 & $0.940^{\mathrm{Aab}}$ & $0.939^{\mathrm{ABab}}$ & $0.944^{\mathrm{ABa}}$ & $0.939^{\mathrm{Bab}}$ & $0.936^{\mathrm{Bbc}}$ & $0.932^{\mathrm{Ac}}$ & $0.916^{\mathrm{Bd}}$ & $0.878^{\mathrm{ABe}}$ & $0.860^{\mathrm{Af}}$ & $0.845^{\mathrm{Ag}}$ & $0.826^{\mathrm{ABi}}$ & $0.851^{\mathrm{Ag}}$ & $0.834^{\mathrm{Ah}}$ & 0.002 \\
\hline & KP5 & $0.936^{\mathrm{Ab}}$ & $0.935^{\mathrm{Bb}}$ & $0.942^{\mathrm{Ba}}$ & $0.938^{\mathrm{Bb}}$ & $0.934^{\mathrm{Bb}}$ & $0.929^{\mathrm{Ac}}$ & $0.918^{\mathrm{Bd}}$ & $0.875^{\mathrm{Be}}$ & $0.858^{\mathrm{Af}}$ & $0.829^{\mathrm{Ch}}$ & $0.819^{\mathrm{Bi}}$ & $0.854^{\mathrm{Ag}}$ & $0.830^{\mathrm{Ah}}$ & 0.001 \\
\hline & SEM & 0.001 & 0.002 & 0.001 & 0.001 & 0.001 & 0.002 & 0.002 & 0.002 & 0.002 & 0.001 & 0.002 & 0.001 & 0.001 & \\
\hline
\end{tabular}

A-D Means within same column with different superscript letters differ significantly at $\mathrm{p}<0.05$.

${ }^{a-j}$ Means within same row with different superscript letters differ significantly at $\mathrm{p}<0.05$.

1) Con, pork salami added with commercial starter; KP1, pork salami added with $1 \%$ kimchi powder; KP3, pork salami added with $3 \%$ kimchi powder; KP5, pork salami added with 5\% kimchi powder. 
and to approximately 0.83 in pork salami with KP by the end of aging period. On day 42 , the Aw values of pork salami in KP5 were lower than the control. Fermented sausages categorized on the basis of final $A_{W}$ values, with sausages having an $A_{W}$ value below 0.90 being termed 'dry' and those with an $A_{W}$ value between 0.90 and 0.95 being considered 'semi-dry' (Park et al., 2012). Therefore, all of sausages in this study were considered dry fermented sausages from day 21. Meat products with pH between 5.2 and 5.0 or Aw between 0.95 and 0.91, are perishable (Papadima and Bloukas, 1999). In addition, sausages with $10 \%$ fat, after 14 days of storage in the ripening room, had $\mathrm{pH}$ values and $\mathrm{Aw}$ levels lower than 0.90 and 5.0, respectively, which characterize them as stable in ambient conditions.

The TBARS values of pork salamis with KP significantly increased during fermentation and aging (Fig. 1). TBARS values generally are used as degree of lipid oxidation, which measures malonaldehyde contents. The TBARS values of pork salami in control, KP1, KP3, and KP5 were 0.04, 0.06, 0.11, and $0.13 \mathrm{mg} \mathrm{MDA} / \mathrm{kg}$, respectively. The final TBARS values of control, $\mathrm{KP} 1, \mathrm{KP} 3$ and KP5 were $0.20,0.11,0.16$ and $0.19 \mathrm{mg} \mathrm{MDA} / \mathrm{kg}$, respectively. However, TBARS values of all pork salamis remained below $0.2 \mathrm{mg} \mathrm{MDA} / \mathrm{kg}$ during aging. Kim et al. (2013) reported that lipid oxidation occurs when the TBARS value is greater than $0.2 \mathrm{mg} \mathrm{MDA} / \mathrm{kg}$. Also, Ahmad and Srivastava (2007) showed that TBARS value of fermented sausage (control) increased by day 75, and all samples (below $0.2 \mathrm{mg} \mathrm{MDA} / \mathrm{kg}$ ) were edible by day 60 , and within safe limits by day 75 during refrigerated storage. Based on these results, pork salamis in this study are considered safe from lipid oxidation.

The textural properties of all pork salamis are listed in Table 4. Cohesiveness of all pork salamis was significantly decreased $(\mathrm{p}<0.05)$. However, hardness, adhesiveness, gumminess, and chewiness of the salamis were significantly increased during ageing. The hardness, gumminess, chewiness, and cohesiveness of pork salami with KP decreased as the concentration of KP increased. The adhesiveness of pork salami was not affected by the addition of KP.

The CIE L*, a* and $b^{*}$ values of all pork salamis after day 1 decreased significantly during fermentation and ageing (Table 5). The $L^{*}$ values of all pork salamis were $49.52-57.75$ at the initial phase, decreased significantly as ageing progressed, and were the lowest at end of ageing (31.60-35.09). The $a^{*}$ values of all pork salamis at the initial phase were 5.49-13.05 and increased at day 1 (11.23-15.97), and then decreased significantly as ageing period progressed, reaching the lowest at end of ageing period (4.83-10.94). The $b^{*}$ values of all treatments also decreased significantly from the initial phase (14.51-30.55) to the final phase (7.88-13.35) and were the lowest at the end of ageing. The $\mathrm{L}^{*}$ value of the control was significantly

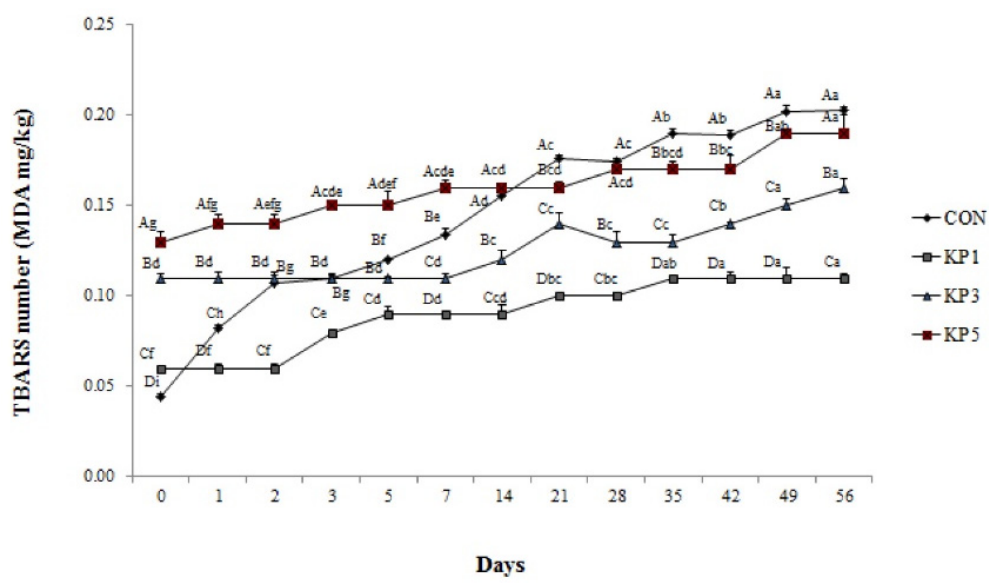

Fig. 1. TBARS values of pork salami added with different concentrations of kimchi powder. ${ }^{A-D}$ Values with different letters among treatments differ significantly at $p<0.05$. ${ }^{a-g}$ Values with different letters during ageing differ significantly at $p<0.05$. Con, pork salami added with commercial starter; KP1, pork salami added with $1 \%$ kimchi powder; KP3, pork salami added with $3 \%$ kimchi powder; KP5, pork salami added with $5 \%$ kimchi powder; TBARS, Thiobarbituric acid reaction substances. 
Table 4. Texture profile analysis of pork salami added with different level of kimchi powder

\begin{tabular}{|c|c|c|c|c|c|c|c|c|c|c|}
\hline \multirow{2}{*}{ Items } & \multirow{2}{*}{ Treatment ${ }^{1)}$} & \multicolumn{9}{|c|}{ Days } \\
\hline & & 7 & 14 & 21 & 28 & 35 & 42 & 49 & 56 & SEM \\
\hline \multirow{5}{*}{$\begin{array}{l}\text { Hardness } \\
\text { (kgf) }\end{array}$} & $\mathrm{CON}$ & $4.41^{\mathrm{Ah}}$ & $5.30^{\mathrm{Ag}}$ & $5.95^{\mathrm{ABf}}$ & $7.12^{\mathrm{Ae}}$ & $9.17^{\mathrm{Bd}}$ & $10.65^{\mathrm{Ac}}$ & $11.37^{\mathrm{Ab}}$ & $12.53^{\mathrm{Aa}}$ & 0.148 \\
\hline & KP1 & $3.52^{\mathrm{Bf}}$ & $5.27^{\mathrm{Ae}}$ & $6.16^{\mathrm{Ad}}$ & $6.93^{\mathrm{Ac}}$ & $10.50^{\text {Aab }}$ & $10.03^{\mathrm{Ab}}$ & $10.64^{\mathrm{Ba}}$ & $10.50^{\mathrm{Bab}}$ & 0.184 \\
\hline & KP3 & $3.40^{\mathrm{BCg}}$ & $4.74^{\mathrm{Bf}}$ & $5.67^{\mathrm{Be}}$ & $6.34^{\mathrm{Bd}}$ & $9.01^{\mathrm{BCb}}$ & $8.86^{\mathrm{Bbc}}$ & $8.42^{\mathrm{Cc}}$ & $11.05^{\mathrm{Ba}}$ & 0.174 \\
\hline & KP5 & $3.04^{\mathrm{Cc}}$ & $3.57^{\mathrm{Cc}}$ & $4.92^{\mathrm{Cb}}$ & $5.21^{\mathrm{Cb}}$ & $8.60^{\mathrm{Ca}}$ & $8.21^{\mathrm{Ba}}$ & $8.65^{\mathrm{Ca}}$ & $8.32^{\mathrm{Ca}}$ & 0.197 \\
\hline & SEM & 0.131 & 0.114 & 0.115 & 0.164 & 0.153 & 0.254 & 0.220 & 0.207 & \\
\hline \multirow{5}{*}{$\begin{array}{l}\text { Adhesiveness } \\
(\mathrm{Nmm})\end{array}$} & $\mathrm{CON}$ & $0.07^{\mathrm{Ad}}$ & $0.13^{\text {Acd }}$ & $0.13^{\text {Acd }}$ & $0.15^{\mathrm{Abc}}$ & $0.21^{\mathrm{Aab}}$ & $0.21^{\mathrm{Bab}}$ & $0.23^{\mathrm{Aa}}$ & $0.25^{\mathrm{Aa}}$ & 0.023 \\
\hline & KP1 & $0.07^{\mathrm{Ac}}$ & $0.09^{\mathrm{Abc}}$ & $0.11^{\text {Aabc }}$ & $0.14^{\text {Aabc }}$ & $0.13^{\text {Aabc }}$ & $0.13^{\mathrm{Babc}}$ & $0.15^{\mathrm{Bab}}$ & $0.18^{\mathrm{Aa}}$ & 0.023 \\
\hline & KP3 & $0.07^{\mathrm{Ad}}$ & $0.10^{\text {Acd }}$ & $0.13^{\mathrm{Abc}}$ & $0.15^{\mathrm{Aab}}$ & $0.16^{\mathrm{Aab}}$ & $0.16^{\mathrm{ABab}}$ & $0.18^{\mathrm{ABab}}$ & $0.20^{\mathrm{Aa}}$ & 0.014 \\
\hline & KP5 & $0.09^{\mathrm{Ac}}$ & $0.12^{\mathrm{Abc}}$ & $0.15^{\mathrm{Aab}}$ & $0.18^{\mathrm{Aa}}$ & $0.018^{\mathrm{Aa}}$ & $0.18^{\mathrm{ABa}}$ & $0.19^{\mathrm{ABa}}$ & $0.21^{\mathrm{Aa}}$ & 0.018 \\
\hline & SEM & 0.008 & 0.013 & 0.017 & 0.024 & 0.025 & 0.017 & 0.020 & 0.028 & \\
\hline \multirow{5}{*}{$\begin{array}{l}\text { Gumminess } \\
\text { (kgf) }\end{array}$} & $\mathrm{CON}$ & $2.50^{\mathrm{Af}}$ & $2.86^{\text {Aef }}$ & $3.17^{\text {Ade }}$ & $3.34^{\mathrm{Ad}}$ & $3.95^{\mathrm{Ac}}$ & $4.31^{\mathrm{Abc}}$ & $4.68^{\mathrm{Ab}}$ & $5.49^{\mathrm{Aa}}$ & 0.151 \\
\hline & KP1 & $2.14^{\mathrm{Bf}}$ & $2.67^{\mathrm{Ae}}$ & $3.08^{\text {Ade }}$ & $3.23^{\mathrm{ABcd}}$ & $3.60^{\mathrm{ABbc}}$ & $4.04^{\mathrm{Aab}}$ & $4.25^{\mathrm{Aa}}$ & $4.35^{\mathrm{Ba}}$ & 0.161 \\
\hline & KP3 & $1.75^{\mathrm{Ce}}$ & $2.36^{\mathrm{Bd}}$ & $2.69^{\mathrm{Bcd}}$ & $2.95^{\mathrm{ABbc}}$ & $3.11^{\mathrm{BCb}}$ & $3.13^{\mathrm{Bb}}$ & $3.23^{\mathrm{Bb}}$ & $3.75^{\mathrm{Ca}}$ & 0.128 \\
\hline & KP5 & $1.72^{\mathrm{Cd}}$ & $1.90^{\mathrm{Cd}}$ & $2.53^{\mathrm{Bc}}$ & $2.89^{\mathrm{Bbc}}$ & $3.04^{\mathrm{Cab}}$ & $3.11^{\mathrm{Bab}}$ & $3.25^{\mathrm{Bab}}$ & $3.33^{\mathrm{Ca}}$ & 0.129 \\
\hline & SEM & 0.103 & 0.094 & 0.111 & 0.124 & 0.163 & 0.189 & 0.168 & 0.162 & \\
\hline \multirow{5}{*}{$\begin{array}{l}\text { Chewiness } \\
\text { (kgf) }\end{array}$} & $\mathrm{CON}$ & $1.70^{\mathrm{Ae}}$ & $1.82^{\mathrm{Ae}}$ & $2.24^{\mathrm{Ad}}$ & $2.72^{\mathrm{ABc}}$ & $3.31^{\mathrm{Ab}}$ & $3.54^{\mathrm{Ab}}$ & $3.57^{\mathrm{Ab}}$ & $4.10^{\mathrm{Aa}}$ & 0.111 \\
\hline & KP1 & $1.34^{\mathrm{Bf}}$ & $1.60^{\mathrm{ABe}}$ & $2.30^{\mathrm{Ad}}$ & $2.79^{\mathrm{Ac}}$ & $3.10^{\mathrm{Bb}}$ & $3.03^{\mathrm{Bbc}}$ & $3.05^{\mathrm{Bb}}$ & $3.48^{\mathrm{Ba}}$ & 0.085 \\
\hline & KP3 & $1.28^{\mathrm{Bd}}$ & $1.46^{\mathrm{BCd}}$ & $1.86^{\mathrm{Bc}}$ & $2.47^{\mathrm{BCb}}$ & $2.52^{\mathrm{Cb}}$ & $2.50^{\mathrm{Cb}}$ & $2.54^{\mathrm{Cb}}$ & $3.05^{\mathrm{Ca}}$ & 0.095 \\
\hline & KP5 & $1.28^{\mathrm{Be}}$ & $1.31^{\mathrm{Ce}}$ & $1.86^{\mathrm{Bd}}$ & $2.34^{\mathrm{Cbc}}$ & $2.49^{\mathrm{Cb}}$ & $2.32^{\mathrm{BCc}}$ & $2.21^{\mathrm{Dc}}$ & $2.84^{\mathrm{Ca}}$ & 0.087 \\
\hline & SEM & 0.072 & 0.074 & 0.090 & 0.086 & 0.064 & 0.145 & 0.077 & 0.123 & \\
\hline \multirow[t]{5}{*}{ Cohesiveness } & $\mathrm{CON}$ & $0.53^{\mathrm{Aa}}$ & $0.50^{\mathrm{Ab}}$ & $0.50^{\mathrm{Ab}}$ & $0.44^{\mathrm{Ac}}$ & $0.41^{\mathrm{Ac}}$ & $0.39^{\mathrm{Ad}}$ & $0.39^{\mathrm{Ae}}$ & $0.39^{\mathrm{Ae}}$ & 0.005 \\
\hline & KP1 & $0.54^{\mathrm{Aa}}$ & $0.50^{\mathrm{ABb}}$ & $0.50^{\mathrm{Ab}}$ & $0.45^{\mathrm{Ac}}$ & $0.42^{\mathrm{Ad}}$ & $0.38^{\mathrm{Be}}$ & $0.37^{\mathrm{Be}}$ & $0.38^{\mathrm{Be}}$ & 0.004 \\
\hline & KP3 & $0.52^{\mathrm{Ba}}$ & $0.47^{\mathrm{Cb}}$ & $0.45^{\mathrm{Bc}}$ & $0.43^{\mathrm{Bd}}$ & $0.39^{\mathrm{Be}}$ & $0.37^{\mathrm{Cf}}$ & $0.36^{\mathrm{BCf}}$ & $0.36^{\mathrm{Bf}}$ & 0.005 \\
\hline & KP5 & $0.48^{\mathrm{Ca}}$ & $0.49^{\mathrm{Cab}}$ & $0.45^{\mathrm{Bb}}$ & $0.43^{\mathrm{Bc}}$ & $0.39^{\mathrm{Bd}}$ & $0.37^{\mathrm{Ce}}$ & $0.35^{\mathrm{Cf}}$ & $0.35^{\mathrm{Cf}}$ & 0.004 \\
\hline & SEM & 0.006 & 0.006 & 0.003 & 0.002 & 0.004 & 0.003 & 0.005 & 0.004 & \\
\hline
\end{tabular}

${ }^{\mathrm{A}-\mathrm{C}}$ Means within same column with different superscript letters differ significantly at $\mathrm{p}<0.05$.

${ }^{\mathrm{a}-\mathrm{h}}$ Means within same row with different superscript letters differ significantly at $\mathrm{p}<0.05$.

${ }^{1)}$ Con, pork salami added with commercial starter; KP1, pork salami added with $1 \%$ kimchi powder; KP3, pork salami added with $3 \%$ kimchi powder;

KP5, pork salami added with $5 \%$ kimchi powder.

higher than that of pork salami with KP on day 7 and 14 , and of the $\mathrm{L}^{*}$ value of pork salami with KP decreased as the concentration of KP increased. On the other hand, the $\mathrm{a}^{*}$ and $\mathrm{b}^{*}$ values were higher in pork salami with KP than in the control and were depend on concentration of KP. Lee et al. (2008) reported that capsaicin, cryptoxanthin, and $\beta$-carotene, in particular those of the carotenoid group, may increase the $\mathrm{a}^{*}$ values in pork salami with KP.

The sensory properties of all pork salamis were presented in Table 6 . The color scores of all sausages significantly decreased during the aging period and were $6.42-7.57$ at day 7 and 5.00-6.57 at day 56. The flavor scores of all pork salamis remained until day 42 , however, significantly decreased at day 49 and 56, and were the lowest at the end of the aging period, but there was no significant difference among treatments. Lee et al. (2008) reported that taste and flavor increased with the 
Table 5. Changes in CIE color ( $L^{*}, a^{*}$, and $\left.b^{*}\right)$ of pork salami added with different level of kimchi powder

\begin{tabular}{|c|c|c|c|c|c|c|c|c|c|c|c|c|c|c|c|}
\hline \multirow{2}{*}{\multicolumn{2}{|c|}{ Items treatment ${ }^{1}$}} & \multicolumn{14}{|c|}{ Days } \\
\hline & & 0 & 1 & 2 & 3 & 5 & 7 & 14 & 21 & 28 & 35 & 42 & 49 & 56 & SEM \\
\hline \multirow[t]{5}{*}{$\mathrm{L}^{*}$} & $\mathrm{CON}$ & $57.75^{\mathrm{Aa}}$ & $57.40^{\mathrm{Aa}}$ & $48.87^{\mathrm{Ab}}$ & $48.08^{\mathrm{Ac}}$ & $44.56^{\mathrm{Bd}}$ & $40.88^{\mathrm{Be}}$ & $38.15^{\mathrm{Af}}$ & $36.62^{\mathrm{Ag}}$ & $34.90^{\mathrm{Ah}}$ & $33.11^{\mathrm{Bj}}$ & $33.76^{\mathrm{Ai}}$ & $35.01^{\mathrm{Ah}}$ & $35.09^{\mathrm{Ah}}$ & 0.156 \\
\hline & KP1 & $56.44^{\mathrm{Aa}}$ & $52.38^{\mathrm{Bb}}$ & $46.75^{\mathrm{Bd}}$ & $47.96^{\mathrm{Ac}}$ & $47.91^{\mathrm{Ac}}$ & $42.69^{\mathrm{Ae}}$ & $37.39^{\mathrm{Bf}}$ & $36.26^{\mathrm{Ag}}$ & $34.46^{\mathrm{Ah}}$ & $33.60^{\mathrm{Ai}}$ & $33.43^{\mathrm{ABi}}$ & ${ }^{\mathrm{i}} 33.83^{\mathrm{Bhi}}$ & $33.18^{\mathrm{Bi}}$ & 0.272 \\
\hline & KP3 & $52.74^{\mathrm{Ba}}$ & $49.24^{\mathrm{Cb}}$ & $44.22^{\mathrm{Cd}}$ & $45.96^{\mathrm{Bc}}$ & $43.28^{\mathrm{Ce}}$ & $40.38^{\mathrm{Cf}}$ & $36.45^{\mathrm{Cg}}$ & $34.85^{\mathrm{Bh}}$ & $33.44^{\mathrm{Bi}}$ & $32.24^{\mathrm{Cj}}$ & $32.32^{\mathrm{Cj}}$ & $32.45^{\mathrm{Cj}}$ & $33.64^{\mathrm{Bi}}$ & 0.308 \\
\hline & KP5 & $49.52^{\mathrm{Ca}}$ & $48.12^{\mathrm{Db}}$ & $42.19^{\mathrm{De}}$ & $45.28^{\mathrm{Bc}}$ & $43.45^{\mathrm{Cd}}$ & $39.53^{\mathrm{Df}}$ & $35.46^{\mathrm{Dg}}$ & $34.32^{\mathrm{Bh}}$ & $33.36^{\mathrm{Bi}}$ & $32.27^{\mathrm{Cjk}}$ & $32.65^{\mathrm{Bij}}$ & $32.80^{\mathrm{Cij}}$ & $31.60^{\mathrm{Cjk}}$ & ${ }^{k} 0.267$ \\
\hline & SEM & 0.469 & 0.355 & 0.172 & 0.270 & 0.213 & 0.142 & 0.143 & 0.204 & 0.316 & 0.147 & 0.288 & 0.204 & 0.194 & \\
\hline \multirow[t]{5}{*}{$a^{*}$} & $\mathrm{ON}$ & $5.49^{\mathrm{Dg}}$ & $11.23^{\mathrm{Dab}}$ & $11.65^{\mathrm{Cab}}$ & $11.53^{\mathrm{Dab}}$ & $11.62^{\mathrm{Dab}}$ & $11.88^{\mathrm{Da}}$ & $11.10^{\mathrm{Dbc}}$ & $10.60^{\mathrm{Db}}$ & $9.79^{\mathrm{Cc}}$ & $8.61^{\mathrm{De}}$ & $6.51^{\mathrm{Cf}}$ & $4.85^{\mathrm{Dh}}$ & $4.83^{\mathrm{Dh}}$ & 0.206 \\
\hline & KP1 & $7.87^{\mathrm{Cg}}$ & $12.83^{\mathrm{Cc}}$ & $13.00^{\mathrm{Bc}}$ & $13.57^{\mathrm{Cb}}$ & $13.82^{\mathrm{Cab}}$ & $14.27^{\mathrm{Ca}}$ & $12.80^{\mathrm{Cc}}$ & $12.06^{\mathrm{Cd}}$ & $11.52^{\mathrm{Ae}}$ & $9.63^{\mathrm{Cf}}$ & $7.04^{\mathrm{Bh}}$ & $6.56^{\mathrm{Ci}}$ & $6.47^{\mathrm{Ci}}$ & 0.163 \\
\hline & KP3 & $10.40^{\mathrm{Bfg}}$ & $15.47^{\mathrm{Bb}}$ & $15.47^{\mathrm{Ab}}$ & $15.76^{\mathrm{Bab}}$ & $15.87^{\mathrm{Ba}}$ & $15.41^{\mathrm{Bb}}$ & $14.42^{\mathrm{Bc}}$ & $12.95^{\mathrm{Bd}}$ & $10.84^{\mathrm{Be}}$ & $10.59^{\mathrm{Bef}}$ & ${ }^{f} 10.37^{\mathrm{Afg}}$ & $10.18^{\mathrm{Bg}}$ & $9.58^{\mathrm{Bh}}$ & 0.115 \\
\hline & KP5 & $13.05^{\mathrm{Af}}$ & $15.97^{\mathrm{Ac}}$ & $15.66^{\mathrm{Ac}}$ & $16.67^{\mathrm{Aab}}$ & $16.92^{\mathrm{Aa}}$ & $16.47^{\mathrm{Ab}}$ & $15.09^{\mathrm{Ad}}$ & $13.60^{\mathrm{Ae}}$ & $11.85^{\mathrm{Ag}}$ & $11.50^{\mathrm{Ag}}$ & $10.66^{\mathrm{Ah}}$ & $10.61^{\mathrm{Ah}}$ & $10.94^{\mathrm{Ah}}$ & 0.130 \\
\hline & SEM & נIJ) & 1100 & 0.173 & 0.120 & 0.065 & 0.259 & 0.173 & 0.117 & 0.195 & 0.102 & $0.1 / 1$ & 0.131 & 0.097 & \\
\hline \multirow[t]{5}{*}{$b^{*}$} & $\mathrm{CON}$ & $14.51^{\mathrm{Da}}$ & $13.45^{\mathrm{Db}}$ & $12.40^{\mathrm{Cc}}$ & $12.23^{\mathrm{Dc}}$ & $11.19^{\mathrm{Dd}}$ & $11.15^{\mathrm{Dd}}$ & $10.02^{\mathrm{De}}$ & $9.64^{\mathrm{De}}$ & $8.64^{\mathrm{Df}}$ & $8.03^{\mathrm{Cg}}$ & $7.91^{\mathrm{Cg}}$ & $7.90^{\mathrm{Cg}}$ & $7.88^{\mathrm{Cg}}$ & 0.182 \\
\hline & KP1 & $22.32^{\mathrm{Ca}}$ & $21.10^{\mathrm{Cb}}$ & $18.46^{\mathrm{Bc}}$ & $17.70^{\mathrm{Cd}}$ & $17.31^{\mathrm{Cd}}$ & $16.60^{\mathrm{Ce}}$ & $13.75^{\mathrm{Cf}}$ & $13.00^{\mathrm{Cg}}$ & $12.60^{\mathrm{Cg}}$ & $11.39^{\mathrm{Bh}}$ & $11.02^{\mathrm{Bhi}}$ & $10.53^{\mathrm{Bi}}$ & $10.68^{\mathrm{Bi}}$ & 0.211 \\
\hline & KP3 & $27.14^{\mathrm{Ba}}$ & $25.46^{\mathrm{Bb}}$ & $22.56^{\mathrm{Ac}}$ & $21.72^{\mathrm{Bd}}$ & $20.65^{\mathrm{Be}}$ & $19.22^{\mathrm{Bf}}$ & $16.22^{\mathrm{Bg}}$ & $15.44^{\mathrm{Bh}}$ & $12.11^{\mathrm{Bj}}$ & $12.04^{\mathrm{Bj}}$ & $13.04^{\mathrm{Ai}}$ & $13.27^{\mathrm{Ai}}$ & $12.95^{\mathrm{Ai}}$ & 0.211 \\
\hline & KP5 & $30.55^{\mathrm{Aa}}$ & $26.81^{\mathrm{Ab}}$ & $23.06^{\text {Ade }}$ & $25.18^{\mathrm{Ac}}$ & $23.65^{\mathrm{Ad}}$ & $22.72^{\mathrm{Ae}}$ & $17.33^{\mathrm{Af}}$ & $16.29^{\mathrm{Ag}}$ & $15.32^{\mathrm{Ah}}$ & $13.47^{\mathrm{Ai}}$ & $13.08^{\mathrm{Ai}}$ & $13.45^{\mathrm{Ai}}$ & $13.35^{\mathrm{Ai}}$ & 0.238 \\
\hline & SEM & 0.329 & 0.125 & 0.195 & 0.249 & 0.219 & 0.143 & 0.225 & 0.162 & 0.133 & 0.245 & 0.174 & 0.254 & 0.198 & \\
\hline
\end{tabular}

A-D Means within same column with different superscript letters differ significantly at $\mathrm{p}<0.05$.

${ }^{a-k}$ Means within same row with different superscript letters differ significantly at $\mathrm{p}<0.05$.

1) Con, pork salami added with commercial starter; KP1, pork salami added with 1\% kimchi powder; KP3, pork salami added with $3 \%$ kimchi powder; KP5, pork salami added with 5\% kimchi powder.

Table 6. Sensory evaluation of pork salami added with different concentrations of kimchi powder

\begin{tabular}{|c|c|c|c|c|c|c|c|c|c|c|}
\hline \multirow{2}{*}{ Items } & \multirow{2}{*}{ Treatment $^{1)}$} & \multicolumn{9}{|c|}{ Days } \\
\hline & & 7 & 14 & 21 & 28 & 35 & 42 & 49 & 56 & SEM \\
\hline \multirow[t]{5}{*}{ Color } & $\mathrm{CON}$ & $6.43^{\mathrm{Ba}}$ & $6.57^{\mathrm{Ba}}$ & $6.29^{\mathrm{Ba}}$ & $6.14^{\mathrm{Ba}}$ & $6.00^{\mathrm{Ba}}$ & $5.86^{\mathrm{Bab}}$ & $5.14^{\mathrm{Cbc}}$ & $5.00^{\mathrm{Bc}}$ & 0.286 \\
\hline & KP1 & $7.43^{\mathrm{Aa}}$ & $7.29^{\mathrm{Aa}}$ & $7.14^{\mathrm{Aab}}$ & $7.07^{\mathrm{Aab}}$ & $7.00^{\mathrm{Aab}}$ & $6.57^{\mathrm{ABbc}}$ & $6.00^{\mathrm{Bcd}}$ & $5.86^{\mathrm{Ad}}$ & 0.210 \\
\hline & KP3 & $7.57^{\mathrm{Aa}}$ & $7.57^{\mathrm{Aa}}$ & $7.43^{\mathrm{Aab}}$ & $7.36^{\text {Aab }}$ & $7.00^{\mathrm{Aabc}}$ & $6.71^{\mathrm{Abc}}$ & $6.71^{\mathrm{Abc}}$ & $6.29^{\mathrm{Ac}}$ & 0.260 \\
\hline & KP5 & $7.29^{\mathrm{Aab}}$ & $7.29^{\mathrm{Aab}}$ & $7.43^{\mathrm{Aa}}$ & 7.14 $\mathrm{Aab}$ & 7.00 $\mathrm{Aab}$ & $6.86^{\mathrm{Aab}}$ & $6.86^{\mathrm{Aab}}$ & $6.57^{\mathrm{Ab}}$ & 0.224 \\
\hline & SEM & 0.226 & 0.222 & 0.264 & 0.177 & 0.289 & 0.254 & 0.233 & 0.289 & \\
\hline \multirow[t]{5}{*}{ Appearance } & $\mathrm{CON}$ & $6.57^{\mathrm{Ba}}$ & $6.71^{\mathrm{Aa}}$ & $6.71^{\mathrm{Ba}}$ & $6.71^{\mathrm{Ba}}$ & $6.43^{\mathrm{Aab}}$ & $6.14^{\mathrm{Aabc}}$ & $5.86^{\mathrm{Bbc}}$ & $5.71^{\mathrm{Bc}}$ & 0.224 \\
\hline & KP1 & $7.00^{\mathrm{Aa}}$ & $7.00^{\mathrm{Aa}}$ & $7.00^{\mathrm{ABa}}$ & $7.00^{\mathrm{ABa}}$ & $6.86^{\mathrm{Aa}}$ & $6.29^{\mathrm{Ab}}$ & $6.00^{\mathrm{ABb}}$ & $6.00^{\mathrm{ABb}}$ & 0.137 \\
\hline & KP3 & $7.14^{\mathrm{Aab}}$ & $7.29^{\mathrm{Aa}}$ & $7.29^{\mathrm{Aa}}$ & $7.29^{\mathrm{Aa}}$ & $6.71^{\mathrm{Aab}}$ & $6.57^{\mathrm{Ab}}$ & $6.57^{\mathrm{Ab}}$ & $6.57^{\mathrm{Ab}}$ & 0.187 \\
\hline & KP5 & $7.14^{\mathrm{Aa}}$ & $7.14^{\mathrm{Aa}}$ & $7.14^{\mathrm{ABa}}$ & $7.14^{\mathrm{ABa}}$ & $6.57^{\mathrm{Aab}}$ & $6.43^{\mathrm{Ab}}$ & $6.43^{\mathrm{ABb}}$ & $6.29^{\mathrm{ABb}}$ & 0.218 \\
\hline & SEM & 0.143 & 0.184 & 0.149 & 0.149 & 0.184 & 0.240 & 0.222 & 0.251 & \\
\hline \multirow[t]{5}{*}{ Odor } & $\mathrm{CON}$ & $6.14^{\mathrm{Ca}}$ & $6.14^{\mathrm{ABa}}$ & $6.00^{\mathrm{Aa}}$ & $5.71^{\mathrm{Aa}}$ & $5.71^{\mathrm{Aa}}$ & $5.43^{\mathrm{Aa}}$ & $5.29^{\mathrm{Aa}}$ & $5.29^{\mathrm{Aa}}$ & 0.262 \\
\hline & KP1 & $6.57^{\mathrm{BCa}}$ & $6.43^{\mathrm{Aa}}$ & $6.29^{\mathrm{Aab}}$ & $6.14^{\mathrm{Aab}}$ & $6.14^{\mathrm{Aab}}$ & $6.00^{\mathrm{Aab}}$ & $5.43^{\mathrm{Ab}}$ & $6.00^{\mathrm{Aab}}$ & 0.300 \\
\hline & KP3 & $6.93^{\mathrm{ABa}}$ & $5.71^{\mathrm{ABab}}$ & $6.14^{\mathrm{Aab}}$ & $6.14^{\mathrm{Aab}}$ & $6.00^{\mathrm{Aab}}$ & $5.86^{\mathrm{Aab}}$ & $6.00^{\mathrm{Aab}}$ & $5.57^{\mathrm{Ab}}$ & 0.412 \\
\hline & KP5 & $7.36^{\mathrm{Aa}}$ & $5.29^{\mathrm{Bb}}$ & $6.14^{\mathrm{Aab}}$ & $6.14^{\mathrm{Aab}}$ & $6.14^{\mathrm{Aab}}$ & $6.57^{\mathrm{Aab}}$ & $6.14^{\mathrm{Aab}}$ & $5.57^{\mathrm{Ab}}$ & 0.421 \\
\hline & SEM & 0.206 & 0.322 & 0.300 & 0.289 & 0.258 & 0.380 & 0.378 & 0.582 & \\
\hline
\end{tabular}


Table 6. Sensory evaluation of pork salami added with different concentrations of kimchi powder (continued)

\begin{tabular}{|c|c|c|c|c|c|c|c|c|c|c|}
\hline \multirow{2}{*}{ Items } & \multirow{2}{*}{ Treatment ${ }^{1)}$} & \multicolumn{9}{|c|}{ Days } \\
\hline & & 7 & 14 & 21 & 28 & 35 & 42 & 49 & 56 & SEM \\
\hline \multirow[t]{5}{*}{ Flavor } & $\mathrm{CON}$ & $6.57^{\mathrm{Aa}}$ & $6.57^{\mathrm{Aa}}$ & $6.43^{\mathrm{Aab}}$ & $6.14^{\mathrm{Aabc}}$ & $6.00^{\mathrm{Aabc}}$ & $6.00^{\mathrm{Aabc}}$ & $5.86^{\mathrm{Bc}}$ & $5.57^{\mathrm{Ac}}$ & 0.193 \\
\hline & KP1 & $6.71^{\mathrm{Aa}}$ & $6.71^{\mathrm{Aa}}$ & $6.57^{\mathrm{Aa}}$ & $6.57^{\mathrm{Aa}}$ & $6.57^{\mathrm{Aa}}$ & $6.43^{\mathrm{Aa}}$ & $6.29^{\mathrm{ABa}}$ & $6.29^{\mathrm{Aa}}$ & 0.222 \\
\hline & KP3 & $6.86^{\mathrm{Aa}}$ & $6.57^{\mathrm{Aa}}$ & $6.57^{\mathrm{Aa}}$ & $6.43^{\mathrm{Aa}}$ & $6.57^{\mathrm{Aa}}$ & $6.43^{\mathrm{Aa}}$ & $6.57^{\mathrm{Aa}}$ & $6.43^{\mathrm{Aa}}$ & 0.237 \\
\hline & KP5 & $6.86^{\mathrm{Aa}}$ & $6.71^{\mathrm{Aa}}$ & $6.43^{\mathrm{Aa}}$ & $6.57^{\mathrm{Aa}}$ & $6.43^{\mathrm{Aa}}$ & $6.57^{\mathrm{Aa}}$ & $6.43^{\mathrm{ABa}}$ & $6.43^{\mathrm{Aa}}$ & 0.259 \\
\hline & SEM & 0.202 & 0.247 & 0.202 & 0.218 & 0.206 & 0.233 & 0.214 & 0.295 & \\
\hline \multirow[t]{5}{*}{ Acidity } & $\mathrm{CON}$ & $4.57^{\mathrm{Cc}}$ & $5.14^{\mathrm{Cb}}$ & $5.86^{\mathrm{Cab}}$ & $6.14^{\mathrm{Ba}}$ & $6.00^{\mathrm{Cab}}$ & $5.86^{\mathrm{Cab}}$ & $5.43^{\text {Cabc }}$ & $5.29^{\mathrm{Babc}}$ & 0.300 \\
\hline & KP1 & $5.29^{\mathrm{BCb}}$ & $5.71^{\mathrm{Cab}}$ & $6.43^{\mathrm{BCa}}$ & $6.43^{\mathrm{Ba}}$ & $6.43^{\mathrm{BCa}}$ & $6.29^{\mathrm{BCa}}$ & $6.07^{\mathrm{BCab}}$ & $5.57^{\mathrm{ABab}}$ & 0.264 \\
\hline & KP3 & $6.29^{\mathrm{ABa}}$ & $6.71^{\mathrm{Ba}}$ & $6.71^{\mathrm{Ba}}$ & $6.86^{\mathrm{ABa}}$ & $6.79^{\mathrm{Ba}}$ & $6.71^{\mathrm{Ba}}$ & $6.57^{\mathrm{Ba}}$ & $6.14^{\mathrm{ABa}}$ & 0.262 \\
\hline & KP5 & $7.29^{\mathrm{Aa}}$ & $7.57^{\mathrm{Aa}}$ & $7.57^{\mathrm{Aa}}$ & $7.36^{\mathrm{Aa}}$ & $7.57^{\mathrm{Aa}}$ & $7.43^{\mathrm{Aa}}$ & $7.29^{\mathrm{Aa}}$ & $6.86^{\mathrm{Aa}}$ & 0.293 \\
\hline & SEM & 0.362 & 0.210 & 0.240 & 0.241 & 0.209 & 0.237 & 0.232 & 0.429 & \\
\hline \multirow[t]{5}{*}{ Preference } & $\mathrm{CON}$ & $6.57^{\mathrm{Aa}}$ & $6.14^{\mathrm{Aa}}$ & $6.00^{\mathrm{Aa}}$ & $5.86^{\mathrm{Ba}}$ & $6.00^{\mathrm{Ba}}$ & $5.86^{\mathrm{Ba}}$ & $5.86^{\mathrm{Aa}}$ & $5.71^{\mathrm{Aa}}$ & 0.270 \\
\hline & KP1 & $6.43^{\mathrm{Aa}}$ & $6.57^{\mathrm{Aa}}$ & $6.57^{\mathrm{Aa}}$ & $6.57^{\mathrm{ABa}}$ & $6.43^{\mathrm{ABa}}$ & $6.43^{\mathrm{Aa}}$ & $6.29^{\mathrm{Aa}}$ & $6.29^{\mathrm{Aa}}$ & 0.212 \\
\hline & KP3 & $6.57^{\mathrm{Aa}}$ & $6.71^{\mathrm{Aa}}$ & $6.71^{\mathrm{Aa}}$ & $6.86^{\mathrm{Aa}}$ & $6.79^{\mathrm{Aa}}$ & $6.71^{\mathrm{Aa}}$ & $6.57^{\mathrm{Aa}}$ & $6.57^{\mathrm{Aa}}$ & 0.257 \\
\hline & KP5 & $6.71^{\mathrm{Aa}}$ & $6.57^{\mathrm{Aa}}$ & $6.43^{\mathrm{Aa}}$ & $6.50^{\mathrm{ABa}}$ & $6.43^{\mathrm{ABa}}$ & $6.57^{\mathrm{Aa}}$ & $6.43^{\mathrm{Aa}}$ & $6.29^{\mathrm{Aa}}$ & 0.298 \\
\hline & SEM & 0.274 & 0.306 & 0.254 & 0.243 & 0.236 & 0.184 & 0.264 & 0.309 & \\
\hline \multirow[t]{5}{*}{ Texture } & $\mathrm{CON}$ & $6.57^{\mathrm{Aa}}$ & $6.14^{\mathrm{Aab}}$ & $6.00^{\mathrm{Aab}}$ & $6.00^{\mathrm{Aab}}$ & $6.00^{\mathrm{Aab}}$ & $5.86^{\mathrm{Aab}}$ & $5.29^{\mathrm{Bbc}}$ & $4.86^{\mathrm{Ac}}$ & 0.287 \\
\hline & KP1 & $6.57^{\mathrm{Aa}}$ & $6.29^{\mathrm{Aa}}$ & $6.14^{\mathrm{Aa}}$ & $6.14^{\mathrm{Aa}}$ & $6.00^{\mathrm{Aab}}$ & $5.86^{\mathrm{Aab}}$ & $5.86^{\mathrm{ABab}}$ & $5.29^{\mathrm{Ab}}$ & 0.256 \\
\hline & KP3 & $6.57^{\mathrm{Aa}}$ & $6.43^{\mathrm{Aa}}$ & $6.43^{\mathrm{Aa}}$ & $6.50^{\mathrm{Aa}}$ & $6.43^{\mathrm{Aa}}$ & $6.43^{\mathrm{Aa}}$ & $6.14^{\mathrm{Aab}}$ & $5.71^{\mathrm{Ab}}$ & 0.221 \\
\hline & KP5 & $6.57^{\mathrm{Aa}}$ & $6.14^{\mathrm{Aa}}$ & $6.43^{\mathrm{Aa}}$ & $6.14^{\mathrm{Aa}}$ & $6.14^{\mathrm{Aa}}$ & $6.29^{\mathrm{Aa}}$ & $5.71^{\mathrm{ABa}}$ & $5.71^{\mathrm{Aa}}$ & 0.269 \\
\hline & SEM & 0.202 & 0.202 & 0.222 & 0.301 & 0.274 & 0.277 & 0.198 & 0.355 & \\
\hline \multirow{5}{*}{$\begin{array}{l}\text { Overall } \\
\text { acceptability }\end{array}$} & $\mathrm{CON}$ & $6.57^{\mathrm{Aa}}$ & $6.21^{\mathrm{Ba}}$ & $6.29^{\mathrm{Ba}}$ & $6.14^{\mathrm{Ba}}$ & $6.29^{\mathrm{Aa}}$ & $6.14^{\mathrm{Ba}}$ & $5.43^{\mathrm{Bb}}$ & $5.29^{\mathrm{Cb}}$ & 0.221 \\
\hline & KP1 & $6.93^{\mathrm{Aa}}$ & $7.00^{\mathrm{Aa}}$ & $7.07^{\mathrm{Aa}}$ & $6.57^{\mathrm{ABab}}$ & $6.57^{\mathrm{Aab}}$ & $6.14^{\mathrm{Bb}}$ & $6.14^{\mathrm{ABb}}$ & $6.07^{\mathrm{Bb}}$ & 0.171 \\
\hline & KP3 & $6.86^{\mathrm{Aa}}$ & $6.57^{\mathrm{ABa}}$ & $6.57^{\mathrm{ABa}}$ & $6.86^{\mathrm{Aa}}$ & $6.86^{\mathrm{Aa}}$ & $7.00^{\mathrm{Aa}}$ & $6.93^{\mathrm{Aa}}$ & $7.00^{\mathrm{Aa}}$ & 0.206 \\
\hline & KP5 & $6.57^{\mathrm{Aa}}$ & $6.07^{\mathrm{Ba}}$ & $6.21^{\mathrm{Ba}}$ & $6.21^{\mathrm{Ba}}$ & $6.29^{\mathrm{Aa}}$ & $6.93^{\mathrm{Aa}}$ & $6.71^{\mathrm{Aa}}$ & $6.43^{\mathrm{AB}}$ & 0.311 \\
\hline & SEM & 0.197 & 0.202 & 0.247 & 0.195 & 0.210 & 0.243 & 0.291 & 0.260 & \\
\hline
\end{tabular}

${ }^{\mathrm{A}-\mathrm{C}}$ Means within same column with different superscript letters differ significantly at $\mathrm{p}<0.05$.

${ }^{a-d}$ Means within same row with different superscript letters differ significantly at $p<0.05$.

${ }^{1)}$ Con, pork salami added with commercial starter; KP1, pork salami added with $1 \%$ kimchi powder; KP3, pork salami added with $3 \%$ kimchi powder;

KP5, pork salami added with 5\% kimchi powder.

levels of KP. The acidity scores of all pork salamis increased throughout the aging period and were higher in pork salamis with KP than in control, which we attribute to the significantly low $\mathrm{pH}$ values of all pork salamis during the aging periods. Overall acceptability of pork salami of KP3 on day 42, 49, and 56 was higher than that of control. Judging by these results, the KP has improved scores of color, appearance, and overall acceptability of salami in comparison with those of control.

\section{Microbiological characteristics of pork salami with KP}

The LAB and total microorganism of pork salami with KP and the control are depicted in Fig. 2. The initial LAB counts of the control and the pork salami with KP ranged from 5.91 to $6.57 \mathrm{Log}$ CFU/g. The LAB counts of the control were higher 

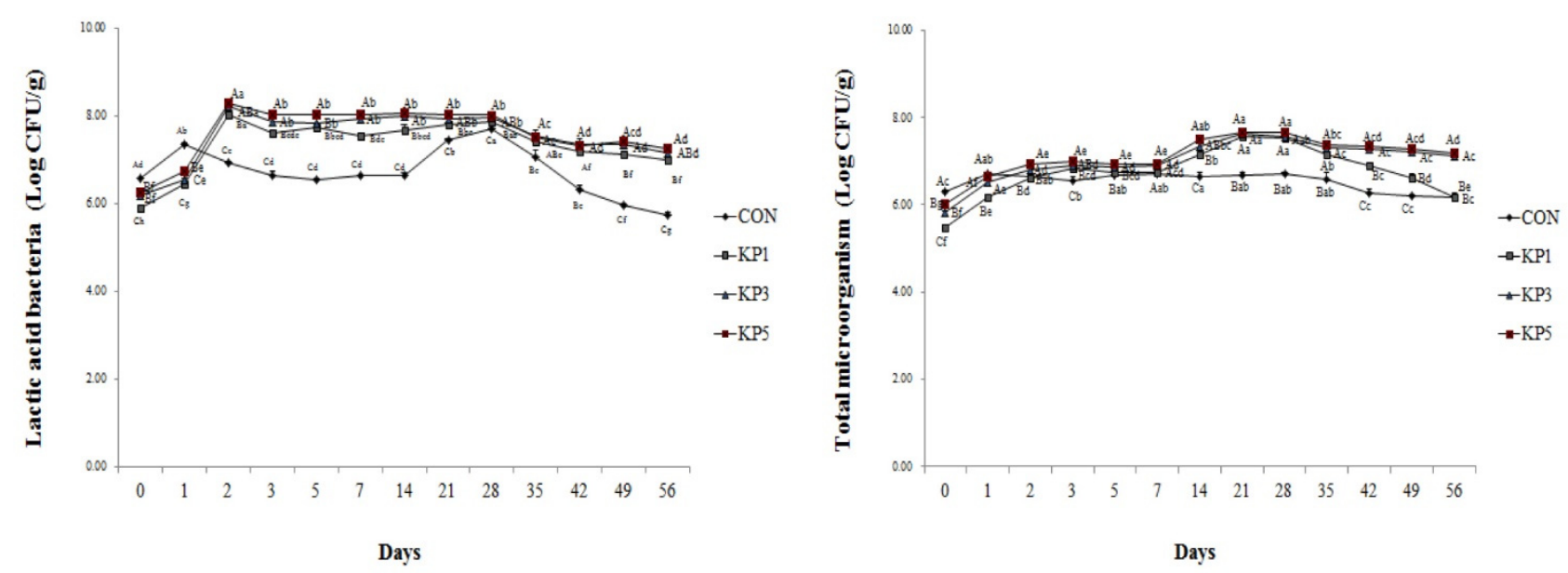

Fig. 2. Number of lactic acid bacteria and total microorganisms of pork salami added with kimchi powder. ${ }^{A-C}$ Values with different letters among treatments differ significantly at $p<0.05 .{ }^{a-f}$ Values with different letters during ageing differ significantly at $p<0.05$. Con, pork salami added with commercial starter; KP1, pork salami added with $1 \%$ kimchi powder; KP3, pork salami added with $3 \%$ kimchi powder; KP5, pork salami added with $5 \%$ kimchi powder.

than that of pork salami with KP at day 1 . After that, LAB counts were significantly higher in pork salami with KP than in control during aging. The LAB counts of pork salami with KP attained maximum levels (8.05-8.31 Log CFU/g) at day 2. Park and Lee (2012) found that the inoculated numbers of LAB achieved by the addition of KP were higher than those of the control. After 1-2 days of fermentation, maximum numbers of LAB were reached. In addition, Chouliara et al. (2006) reported significant growth of LAB within the first four days of fermentation, reflected in the increase of total viable counts (TVC). The fast growth of LAB is critical for the quality and safety of the fermented sausage, because early growth of these bacteria can prevent the growth of deteriorating and pathogenic bacteria (Campagnol et al., 2011). At day 28, the LAB counts of the control were $7.71 \mathrm{Log}$ CFU/g, and the counts of pork salami in KP1, KP3, and KP5 were 7.89, 7.97, and 8.02 Log $\mathrm{CFU} / \mathrm{g}$, respectively. Thereafter, all LAB counts of pork salamis with KP decreased until the end of the aging period. These results revealed that $\mathrm{LAB}$ counts of pork salamis increased as concentration of KP was increased. The most important change during fermentation is the conversion of sugars to lactic acid, so there is a significant correlation between $\mathrm{pH}$ and LAB count. The microflora of sausage during fermentation and aging changes as a result of the combined effects of decreasing the Aw due to drying, lowering the $\mathrm{pH}$, and increasing the brine content, resulting in high numbers of LAB (Muguerza et al, 2002; Palumbo et al., 1976).

The total microorganisms of all pork salamis increased by day 28 , and the numbers were maintained until the end of aging period. The initial numbers of total microorganisms were higher in the control (6.31 Log CFU/g) than in KPs (5.49-6.01 Log $\mathrm{CFU} / \mathrm{g})$. After day 2, the total microorganism counts of KPs increased, and reached maximum levels (7.56-7.67 Log CFU/g) between day 21 to day 28 and decreased. These results indicate that total microorganism counts are similar to the LAB counts. Kang et al. (2012) reported that total bacteria counts of kimchi-fermented sausages with sodium nitrite and green tea extract were similar to $\mathrm{LAB}$ counts during aging periods.

We determined E. coli and coliforms, while these were not detected in the pork salami samples, from the initial phase to the end of the aging period (data not shown). We assumed that the LAB may have inhibited growth of these spoilage and pathogenic bacteria (Ahmad and Srivastava, 2007). The main LAB species of kimchi is Lactobacillus plantarum. Leuconostoc mesenteroides, and the species of L. curvatus, L. plantarum, and L. sakei are established in kimchi, and have 
been described as the dominant lactobacilli in fermenting sausages (Lee et al., 2006; Morishita and Shiromizu, 1986).

The sequence analysis of $16 \mathrm{~S}$ rRNA gene has been used to identify the community of microorganisms that exist in various environments (Lee et al., 2001). The 16S rRNA gene sequence can classify microorganisms to the genus level, and variable regions of specific sequence to the specific species (Han et al., 1998). The size of the PCR products was about 300 base pairs in all pork salamis. The changes in taxa of 16S rRNA genes of LAB in all pork salamis are shown in Fig. 3. The number of Lactobacillus in pork salamis with KP (Fig. 3a) was significantly higher than in the control by day 14. After that, there was no significant difference between treatments from day 21 to the end of the aging period. One study demonstrated that
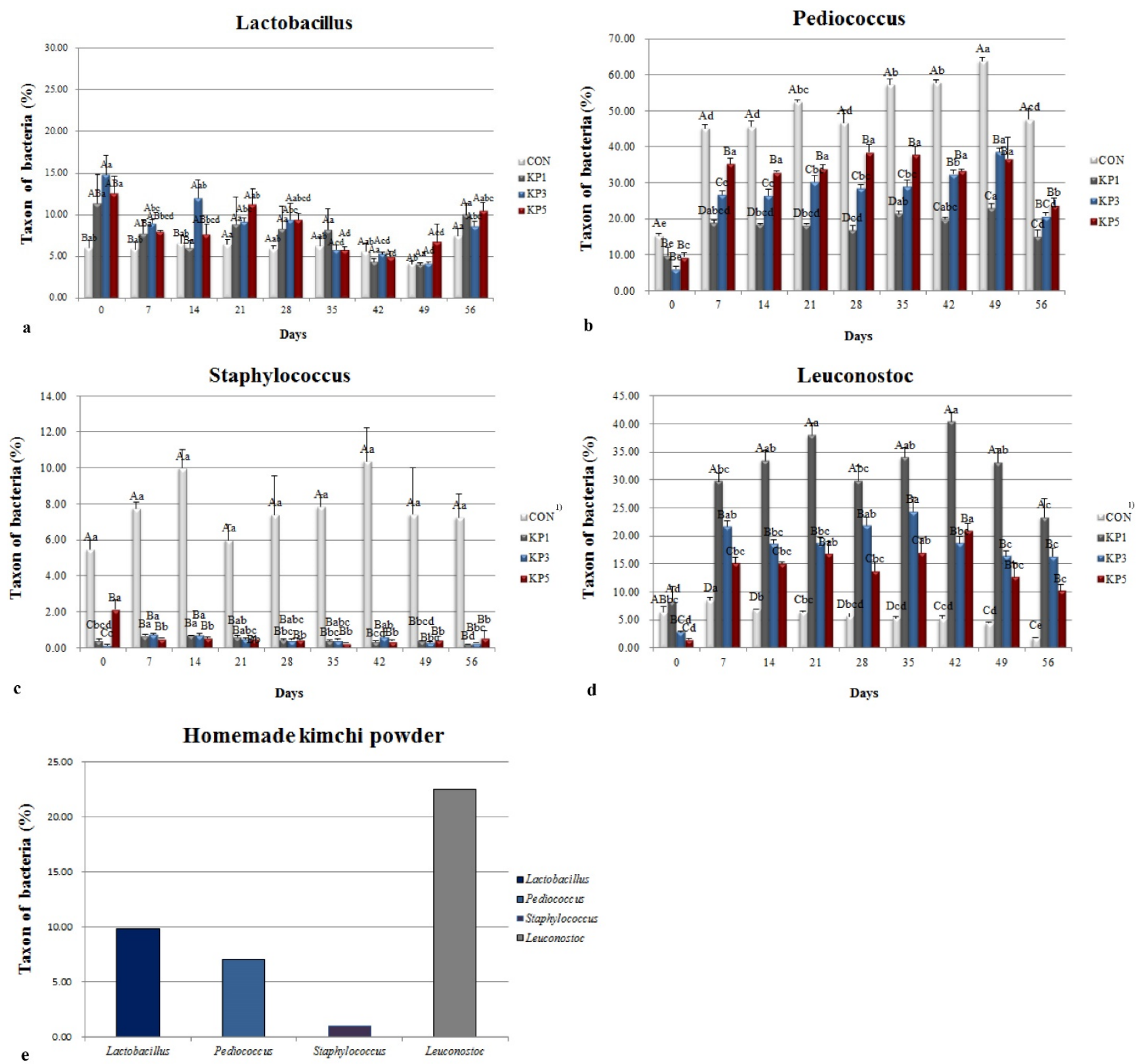

Fig. 3. Changes in taxa of genus Lactobacillus (a), Pediococcus (b), Staphylococcus (c), Leuconostoc (d) of kimchi powder itself (e) and pork salami added with different concentrations of kimchi powder. ${ }^{A-D}$ Values of bar with different letters among treatments differ significantly at $p<0.05$. ${ }^{a-d}$ Values of bar with different letters during ageing differ significantly at $p<0.05$. Con, pork salami added with commercial starter; KP1, pork salami added with $1 \%$ kimchi powder; KP3, pork salami added with $3 \%$ kimchi powder; KP5, pork salami added with $5 \%$ kimchi powder. 
fermented lamb sausage inoculated with the probiotic L. plantarum has a soft texture and enhanced quality (Arief et al., 2014). As mentioned before, pork salamis with KP also showed low hardness, this may due to the probiotic Lactobacilllus. The numbers of Pediococcus (Fig. 3b) and Staphylococcus (Fig. 3c) were significantly higher in the control than in pork salamis with KP, because the starter culture consists of 4 microbes such as Staphylococcus xylosus, Staphylococcus carnosus, Pediococcus acidilactici, and Pediococcus pentosaceus. Although KP contains a low level of Pediococcus spp. (7.05\%), as concentration of KP in pork salami was increased, the numbers of Pediococcus increased significantly. Pork salamis may provide the perfect environment for Pediococcus fermentation. In addition, the numbers of Leuconostoc (Fig. 3d) in pork salamis with KP increased at day 7, and the value was significantly higher than that of control. This result reflects the results of LAB counts in pork salamis with KP, because LAB counts increased from the initial phase to day 7. The counts of Leuconostoc in pork salamis with $1 \% \mathrm{KP}$ and KP itself were the highest, showing $40.45 \%$ and $22.53 \%$, respectively (Fig. 3e). Pork salamis in KP 1 had higher levels of Leuconostoc compared to KP3 and KP5. In contrast, the counts of Leuconostoc in the control was low during the aging periods, due to its absence from the commercial starter. Leuconostoc spp. are regarded as important for the development of flavor and specific taste in fermented sausage, since they produce other metabolites such as lactic acid, acetic acid, dextran, acetaldehyde, diacetyl, and ethanol (Kim and Lee, 2013; Lee et al., 2006).

\section{Conclusions}

This study was performed to investigate the properties of fermented pork salamis with KP, and to characterize their diversity of LAB. In this study, we found that addition of KP to pork salami improves the quality characteristics and enhances texture, flavor, and LAB counts with increasing concentrations of KP. Addition of $1 \% \mathrm{KP}$ to pork salami is most effective due to the resulting high numbers of Leuconostoc bacteria and low TBARS value. Therefore, the KP may serves as a potential natural compounds for fermented meat products like Metzgerei.

\section{Acknowledgements}

This work was carried out with the support of the Cooperative Research Program for Agriculture Science and Technology Development (Project No. PJ009809), Rural Development Administration, Korea and it was partially supported by Brain Korea 21 Plus Project (Human Resource Development for Next Generation Animal Life Industry with ICT-Big Data) from the Ministry of Education and Human Resources Development. Also, this research was supported by the MSIT (Ministry of Science and ICT), Korea, under the ITRC (Information Technology Research Center) support program (IITP-2018-0-01433) supervised by the IITP (Institute for Information \& Communications Technology Promotion).

\section{References}

Ahmad S, Srivastava PK. 2007. Quality and shelf life evaluation of fermented sausages of buffalo meat with different levels of heart and fat. Meat Sci 75:603-609.

AOAC. 1995. Official methods of analysis. $16^{\text {th }}$ ed. AOAC International. Washington, DC, USA.

Arief II, Wulandari Z, Aditia EL, Baihaqi M, Noraimah, Hendrawan. 2014. Physicochemical and microbiological properties of fermented lamb sausages using probiotic Lactobacillus plantarum IIA-2C12 as starter culture. Procedia Environ Sci 20:352-356. 
Aro AJM, Nyam-Osor P, Tsuji K, Shimada KI, Fukushima M, Sekikawa M. 2010. The effect of starter cultures on proteolytic changes and amino acid content in fermented sausages. Food Chem 119:279-285.

Campagnol PCB, dos Santos BA, Wagner R, Terra NN, Pollonio MAR. 2011. The effect of yeast extract addition on quality of fermented sausages at low $\mathrm{NaCl}$ content. Meat Sci 87:290-298.

Chouliara I, Samelis J, Kakouri A, Badeka A, Savvaidis IN, Riganakos K, Kontominas MG. 2006. Effect of irradiation of frozen meat/fat trimmings on microbiological and physicochemical quality attributes of dry fermented sausages. Meat Sci 74:303-311.

Coloretti F, Tabanelli G, Chiavari C, Lanciotti R, Grazia L, Gardini F, Montanari C. 2014. Effect of wine addition on microbiological characteristics, volatile molecule profiles and biogenic amine contents in fermented sausages. Meat Sci 96:1395-1402.

Di Cagno R, Cháves López C, Tofalo R, Gallo G, De Angelis M, Paparella A, Hammes WP, Gobbetti M. 2008. Comparison of the compositional, microbiological, biochemical and volatile profile characteristics of three Italian PDO fermented sausages. Meat Sci 79:224-235.

El-Adawy TA. 2001. Optimum production, stability, partial purification and inhibitory spectrum of antimicrobial compounds produced by Pediococcus pentosaceus DI. Mol Nutr Food Res 45:118-124.

Han SK, Lee IK, Ahn TY. 1998. Bacterial diversity of the Han River as determined by 16S rRNA gene analysis. Kor J Microbiol 34:194-199.

Hugas M. 1998. Bacteriocinogenic lactic acid bacteria for the biopreservation of meat and meat products. Meat Sci 49:139150.

Jang S, Lee J, Jung U, Chio HS, Suh HJ. 2014. Identification of an anti-listerial domain from Pediococcus pentosaceus T1 derived from kimchi, a traditional fermented vegetable. Food Control 43:42-48.

Jo SJ, Oh SM, Jang EK, Hwang K, Lee SP. 2008. Physicochemical properties of carrot juice fermented by Leuconostoc mesenteroides SM. J Korean Soc Food Sci Nutr 37:210-216.

Kang SM, Kim TS, Cho SH, Park BY, Lee SK. 2012. Comparison of microbial and physic-chemical quality characteristics in kimchi-fermented sausages with sodium nitrite and green tea extract. J Ani Sci Technol 54:299-305.

Kim DW, Gil JA, Kim HJ, Kim HW, Park BY, Lee SK, Jang A. 2013. Changes in meat quality and natural di-peptides in the loin and ham cuts of Korean native black pigs during cold storage. J Life Sci 23:1477-1485.

Kim HR, Lee JH. 2013. Selection of acid-tolerant and hetero-fermentative lactic acid bacteria producing non-proteinaceous anti-bacterial substances for kimchi fermentation. Korean J Microbiol Biotechnol 41:119-127.

Kim MJ, Chun JS. 2005. Bacterial community structure in kimchi, a Korean fermented vegetable food, as revealed by $16 \mathrm{~S}$ rRNA gene analysis. Int J Food Microbiol 103:91-96.

Kirk RS, Sawyer R. 1991. General chemical methods. In Pearson's composition and analysis of foods. $9^{\text {th }}$ ed. Longman Scientific \& Technical, Harlow, UK. pp 14-15.

Ko MS, Yang JB. 1999. Changes in flavor components during ripening of fermented sausages. Korean J Food Nutr 12:380386.

Lee JY, Kim CJ, Kunz B. 2006. Identification of lactic acid bacteria isolated from kimchi and studies on their suitability for application as starter culture in the production of fermented sausages. Meat Sci 72:437-445.

Lee MA, Han DJ, Jeong JY, Choi JH, Choi YS, Kim HY, Paik HD, Kim CJ. 2008. Effect of kimchi powder level and drying methods on quality characteristics of breakfast sausage. Meat Sci 80:708-714. 
Lee MS, Hong SK, Lee DH, Kim CK, Bae KS. 2001. Bacterial diversity in the mud flat of sunchon bay, Chunnam province by $16 \mathrm{~S}$ rRNA gene analysis. Korean J Microbiol 37:137-144.

Lee SK, Yoo IJ, Kim YB. Kim KS. 1990. Fermentation of sausage using kimchi. Korean J Anim Sci 32:707-714.

Mcdonald LC, Fleming HP, Hassan HM. 1990. Acid tolerance of Leuconostoc mesenteroides and Lactobacillus plantarum. Appl Environ Microbiol 56:2120-2124.

Morishita Y, Shiromizu K. 1986. Characterization of lactobacilli isolated from meats and meat products. Int J Food Microbiol 3:19-29.

Muguerza E, Fista G, Ansorena D, Astiasaran I, Bloukas JG. 2002. Effect of fat level and partial replacement of pork backfat with olive oil on processing and quality characteristics of fermented sausages. Meat Sci 61:397-404.

Paik HD, Lee JY. 2014. Investigation of reduction and tolerance capability of lactic acid bacteria isolated from kimchi against nitrate and nitrite in fermented sausage condition. Meat Sci 97:609-614.

Palumbo SA, Zaika LL, Kissinger JG, Smith JL. 1976. Microbiology and technology of the pepperoni process. J Food Sci 41:12-17.

Papadima SN, Bloukas JG. 1999. Effect of fat level and storage conditions on quality characteristics of traditional Greek sausages. Meat Sci 51:103-113.

Park EJ, Chun J, Cha CJ, Park WS, Jeon CO, Bae JW. 2012. Bacterial community analysis during fermentation of ten representative kinds of kimchi with barcoded pyrosequencing. Food Microbiol 30:197-204.

Park JM, Shin JH, Gu JG, Yoon SJ, Song JC, Jeon WM, Suh HJ, Chang UJ, Yang CY, Kim JM. 2011. Effect of antioxidant activity in kimchi during a short-term and over-ripening fermentation period. J Biosci Bioeng 112:356-359.

Park KY, Cheigh HS. 2000. Antimutagenic and anticancer effects of lactic acid bacteria isolated from kimchi. Res Bull Kimchi Sci Technol 6:84-90.

Park YS, Lee JY. 2012. The effect of kimchi on the microbiological stability of fermented sausage. Meat Sci 92:721-727.

Shukla R, Goyal A. 2013. Novel dextran from Pediococcus pentosaceus CRAG3 isolated from fermented cucumber with anti-cancer properties. Int J Biol Macromol 62:352-357.

Witte VC, Krause GF, Bailey ME. 1970. A new extraction method for determining 2-thiobarbituric acid values of pork and beef during storage. J Food Sci 35:582-585. 